\title{
Effect of Deficit Irrigation on Dry Matter Yield and Water Productivity of Young Harerghe Coffee Genotypes at Jimma, Southwest Ethiopia
}

\author{
Minda Tadesse \\ Jimma Agricultural Research Center, Ethiopian Agricultural Research Center, Jimma, Ethiopia \\ Email address: \\ mindat9@gmail.com \\ To cite this article: \\ Minda Tadesse. Effect of Deficit Irrigation on Dry Matter Yield and Water Productivity of Young Harerghe Coffee Genotypes at Jimma, \\ Southwest Ethiopia. American Journal of Agriculture and Forestry. Vol. 9, No. 4, 2021, pp. 241-247. doi: 10.11648/j.ajaf.20210904.21
}

Received: July 24, 2021; Accepted: August 6, 2021; Published: August 12, 2021

\begin{abstract}
Coffee plays an important role in Ethiopia's economy; it is a major source of revenue, accounting for almost $70 \%$ of total export earnings. However, the recurrent drought and seasonal moisture deficit impacted the coffee production. Therefore, the experiment was conducted to investigate the performance of Harerghe coffee genotypes under different deficit irrigation levels at Jimma (Malko) in rain shelter. Six Harerghe coffee genotypes seedlings with age of eleven months were subjected to three deficit irrigation levels $(40,80$ and $120 \%$ of ETc) with randomized complete block design, which replicated three times. It was observed that different deficit levels significantly affected water productivity, dry mater yield production and growth traits for all genotypes. Based on mean values of total dry matter production, genotype H-823, H-957 and H-981 were classified as more productive than H-929 and H-979 under 80\%ETc irrigations, while H-929 found to be less productive in terms of dry matter production. The $40 \% \mathrm{ETc}$ of irrigation significantly improved water productivity, but, $120 \% \mathrm{ETc}$ considerably reduced the water productivity of most genotypes. As supply of irrigation increased the water productivity was linearly decreased and opposite trend is observed for dry mater yield and plant growth. Regardless of genotypes, almost all genotypes differentially responded to irrigation amounts, the highest and lowest water productivity had produced from H-823 and H-929, respectively, but similar values was observed among H-857 and H-981. The genotype X irrigation interaction significantly impacted all measured plant traits. Among genotypes, H-823 produced highest water productivity under $80 \% \mathrm{ETc}$ and followed by H-674, H-857 and H-929 under 40\%ETc, while the lowest had from H-981 and H-674 with 120\%ETc. In contrast, the $40 \% \mathrm{ETc}$ significantly reduced dry matter production as well as inhibit plant growth. But, under $80 \% \mathrm{ETc}$ coffee seedlings gave medium water productivity, maximum dry matter and promoted vegetative growth. However, this finding should further proofed with replicated field experiments under different agro-ecological conditions.
\end{abstract}

Keywords: Dry Matter Yield, Water Productivity, Coffee Genotypes, Deficit Irrigation

\section{Introduction}

Coffee is important cash crops produced globally as well as in Africa's particularly in the Ethiopian. The overall global coffee production is estimated to be 165 million bags. From this Africa takes a lion share, particularly Ethiopia produced 7.4 million bags, of which nearly 4.1 million was exported and got 906 million USD earns during 2020 years, which is approximately $70 \%$ of export revenue. The lives of most people in coffee producing areas including Ethiopia mainly depend on an economy generated from this crop. More people in these developing regions directly or indirectly derived their income from coffee [1].

In specific detail, in Ethiopia about $60 \%$ of foreign exchange and $30 \%$ government direct revenue are derived from coffee. Despite government's revenues, more than quarter of its population livelihood typically depend on coffee production and marketing. However, its productivity is quite low as compared to other countries. This is because of occurrence of frequent recurrent drought, lack of improved varieties, and diseases [2].

Likewise, sever moisture deficit and polluting environmental value are frightening agricultural sustainability in developing countries including Africa. In 
general, drought and rise of temperature are the most important climatic limitations for coffee production. Therefore, Coffee is naturally dependant on environment and few rises in temperature can greatly reduce the yield and quality of coffee in coffee growing regions. In view of the climate change, most coffee growing areas expected to be shrinking [3].

A combined method is important to improve plant performance for moisture deficit regions involves the identification and selection of traits that contribute to drought tolerance. A partial list of potentially important traits might include water-extraction efficiency, water productivity, hydraulic conductance, osmotic and elastic adjustments, and modification of leaf area. Most of these traits are complex, and their control and molecular basis are not well understood [4].

Boosting irrigation efficiency would therefore reduce the demand of developing new infrastructure to supply additional water for all sectors by 2025 by roughly one half [5]. For instance, farmers may expect to minimize water use either with cultivation of water efficient crops or adopting water efficient irrigation technologies [6].

Hence, just to enhance water productivity requires both improved variety and good agronomic management. The problem is to deal with the crop or improve its genetic makeup [7]. Productivity defined as how the output volume is produced with efficient utilization of input resource without waste [8]. Similarly in crops, due to water scarcity aligned with escalating demand of different sectors, enhancing water productivity and reducing agricultural water usage plays significant role in saving existing water to meet the environmental demand by leaving a sufficient amount of water in the river and lakes and to meet the demand of industries and cities. In general, water productivity is the amount of carbon assimilated (biomass produced) or crop yield per unit of water used [9].

The stomata closure and open primarily controlled by amount of water added to soil and, therefore crop yield and actual evapotranspiration is driven by this physiological process. In given climate and crop cultivar there is well wellknown direct association between plant biomass and transpiration [10]. As irrigation amount reduced, the crop yield becomes reduced. However, the quality may be improved by some extents [11]. Plants use available water in the soil optimally. In addition, the mechanism by which plants lessen evapotranspiration is either by closing stomatal or reduction of leaf area, beside in retarding plant growth. In some cases the intentional imposition of moisture stress is required. For example, the water productivity of medicinal and aromatic plants increases under drought conditions [12].

Water productivity greatly varied among crop species which is mainly related to different carboxylation pathways [13]. Even for the same plant species, the water productivity varied between genotypes and which means, the water productivity is controlled by plant genes [14]. Breeders had been able to develop new high yielding cultivar, but require higher water to produce higher yield. There is direct relationship between the amounts of water transpired by plant with that of growth and yield [15].

The concept of water productivity is crucial, while water remains a limited and costly resource. To increase coffee yield under such limiting water, it needs selection of water efficient genotypes and generating efficient irrigation amounts that enable us to boost water productivity and thereby overcome water shortage in water limiting areas, either in amount or accessibility. Developing new varieties that demonstrate better ability to improve water productivity through innovative research approach will help to modernize all crop production [16].

Therefore, this study was aimed at screening of water efficient Harerghe coffee genotypes under varies irrigation levels in rain shelter.

\section{Materials and Methods}

The experiment was executed from March 25, 2020 to September 4, 2020 in a rain shelter at Melko (JARC), Jimma, Ethiopia. The research center is found at $7^{\circ} 40^{\prime} 05^{\prime \prime} \mathrm{N}$ latitude, $36^{\circ} 47^{\prime} 09^{\prime \prime} \mathrm{E}$ longitude, and with altitude of $1746 \mathrm{~m}$ above asl. The average rainfall of the center was $1541 \mathrm{~mm}$. The monthly mean temperature reached peak $\left(25.8^{\circ} \mathrm{C}\right)$ during March and getting lowest $\left(11.3^{\circ} \mathrm{C}\right)$ during July. The mean monthly relative humidity was $67.2 \%$.

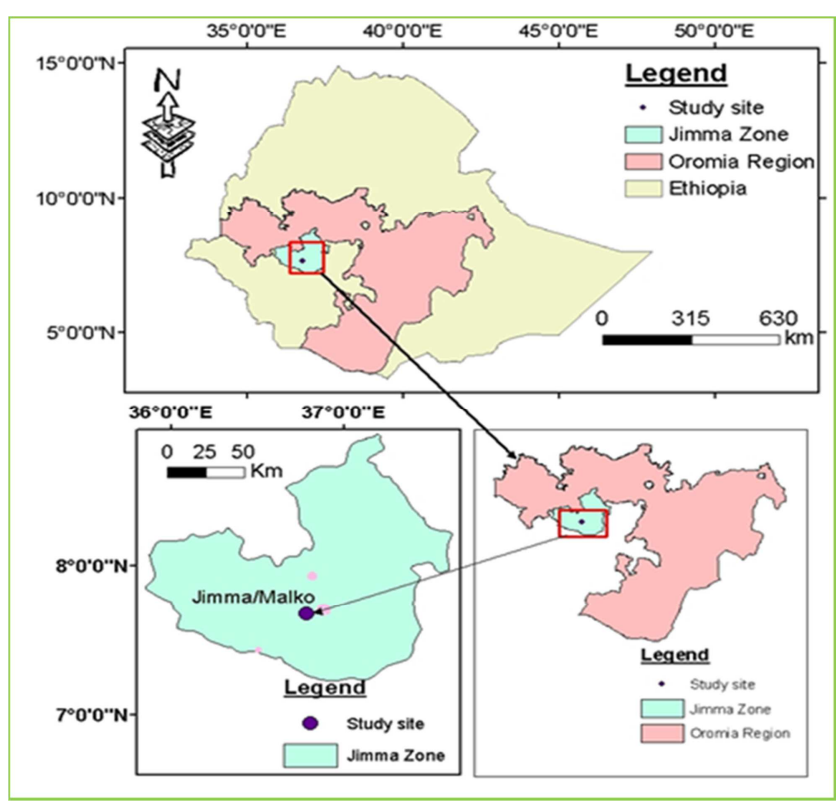

Figure 1. Study area map.

\subsection{Experimental Design}

The experiment was conducted in a factorial RCBD which replicated three times that involved six Harerghe genotypes (H-674/98, H-739/98, H-823/98, H-981/98, and H-929/98 and $\mathrm{H}-857 / 98)$ and three irrigation levels.

Each variety was combined with three irrigation amounts (6 genotype $\mathrm{X} 3$ irrigation treatments), then combined treatments were randomly allocated to experimental plots. Each experimental block contained 18 plots, six irrigated with $40 \% \mathrm{ETc}$, six irrigated with $80 \% \mathrm{ETc}$ and six irrigated 
with $120 \%$ ETc, eight plants per plot and totally, 432 plants were evaluated in this experiment. All irrigation treatments were scheduled at four days intervals, based on field capacity determination and daily evaporation, accordingly, individual varieties subjected to three irrigation amounts, namely, 40, 80 and $120 \%$ ETc.

\subsection{Planting Material}

The released pure seeds of six Harerghe coffee genotypes were collected and sown on the nursery, managed according to recommended nursery mgt standards, vigor and healthy seedling of eleven months old had transplanted to the pots of 5 litr volume in rain shelter. One seedling was planted in each pot and watered to FC to facilitate good establishment.

\subsection{Parameter Measurements}

The first response measurements were made after five days of treatment application and continued till harvesting. A destructive sampling method was used for determination of total-dry matter production. The four representative plants selected from each plot were harvested, then allocated in to leaves, stem and roots, and oven-dried at $70^{\circ} \mathrm{C}$ to a constant weight to determine total dry matter yield. Plant height was measured using a graduated ruler from base stem to apical bud. Girth was measured with a digital caliper in the stem base region. The roots were immersed and washed in clean water to remove adhering soil. The total leaf area was determined with the leaf area meter. Number of nodes and leaf number were determined by physical counting from destructed seedling. The water productivity of each treatment estimated using the following formula:

$$
\mathrm{WP}=\frac{\mathrm{TDY}}{\mathrm{W}}
$$

Where, WP was water productivity, TDY was total dry matter yield and $\mathrm{W}$ was the volume of consumed water.

\subsection{Field Capacity Determination}

Sun-dried nursery soil was filled in pots, each with five liters capacity. The pots were weighed and watered to drip point, covered with a polyethylene sheet to prevent evaporation and placed on a wooden frame bed raised above the ground level to allow free drainage for 24 hours. Next the pots were reweighed to determine the field capacity (FC) of the soil. The moisture content on dry weight basis was determined by gravimetric method (drying soil samples in an oven at $105^{\circ} \mathrm{C}$ to a constant weight); using $150-200 \mathrm{~g}$ wet soil samples taken from wetted pots just after $24 \mathrm{hrs}$ and the loss of water on daily base were estimated on $\mathrm{v} / \mathrm{v}$ of percent. Accordingly, the amount of irrigation water needed per day was calculated from initial minus final pot weight and scheduling was done accordingly.

\subsection{Data Analysis}

The collected data were subjected to statistically analyses using R-software version 4.0.4 using agricolae package.
Finally, the mean separation were done using LSD test. Lastly, the growth parameters were correlated with water productivity.

\section{Result and Discussion}

\subsection{Agronomic Parameter}

The plant growth traits like girth and leaf area were significantly differed due to variety and irrigation interaction, but plant height, number of nodes and tap root length were not affected. The tallest plant height was produced by $\mathrm{H}-$ $823 / 98(46.41 \mathrm{~cm})$ under $80 \% \mathrm{ETc}$, whereas shortest from $\mathrm{H}$ $674(30.5 \mathrm{~cm})$ under $40 \%$ ETc. Furthermore, for most varieties, the shortest plant was produced from $40 \% \mathrm{ETc}$ and whiles the longest had from $80 \% \mathrm{ETc}$. This implies that, the severe soil moisture retards plant growth and moist soil can highly promote plant growth. Plant height was increased with increasing soil moisture at some extent and started to drops at $120 \%$ ETc. As [17] discovered that plant height increased rapidly as the amount of water went up in each growing period. Both extreme events, excessive and lower amount of water significantly affected tobacco growth. Under such extreme condition, the cell elongation will be inhibited and cause retarded growth. Moreover, excessive irrigation quantity made a waste of water at the point of considering saving-water and high efficiency.

Similar to plant height, the stem girth was considerably affected due to variety and irrigation. Accordingly, the thickest plants were produced from H-739/98 $(0.79 \mathrm{~cm})$ under $80 \%$ ETc and while the thin from H-674 $(0.52 \mathrm{~cm})$ under $40 \%$ ETc irrigation level. In general, the plants treated within $40 \%$ ETc produced thinnest plants relatively, which was about $37 \%$ thinner than $80 \%$ ETc and $120 \%$ ET. Even though, plants treated with $80 \%$ and $120 \%$ ETc produced thickest stem girth, but they were not statically differed from each other. H-823 (12.5) produced lot of nodes than other varieties and the fewer had from H-929 (11.67), but there were no significance difference among H-857/98 and H- 739 genotypes. The $40 \% \mathrm{ETc}$ surprisingly reduced number of nodes by about $16.7 \%$ and $13.9 \%$ over $120 \%$ ETc and $80 \%$ ETc respectively.

The leaf area was significantly $(\mathrm{p}<0.05)$ affected both by irrigation and variety. Regardless of varieties, the widest leaf areas were produced from $\mathrm{H}-823$ and $\mathrm{H}-674$, while the narrow got from $\mathrm{H}-981$ and $\mathrm{H}-929$. Irrespective to irrigation, $40 \%$ ETc reduced the leaf area of the coffee seedlings by about $14.5 \%$ and $4.4 \%$ over $120 \%$ and $80 \%$ ETc, respectively. The H-857 $\left(20.88 \mathrm{~cm}^{2}\right)$ and H-674 $\left(18.31 \mathrm{~cm}^{2}\right)$ had produced the narrow leaf area under $40 \% \mathrm{ETc}$ and while wider leaf area had from H-981 under $80 \%$ ETc and followed by H-674 and H-929 under $120 \%$ irrigation level. This indicated that severe moisture stress $(40 \% \mathrm{ETc})$ had significantly reduced the leaf area of the coffee seedling, but some genotypes adjusting themselves with maintaining lower leaf area in order to reduce the evaporating surface, thereby conserve existing moisture and retarding growth in leaves. As soil moisture 
increases the leaf area increases and vice versa. This could related to [18], the plant has mechanism of adjusting itself to reduced soil moisture either by reducing its leaf area to reduce evaporating surface or retard shoot growth, rather invest growth into root parts as drought become progressed. The Author [19] reported that plants in well-watered plots exhibited significantly higher shoot growth, expressed as plant height, girth at the base, number of nodes, internodes length, number of branches, total branch length, number of leaves and total leaf area. According to [20] pointed out that water stress decreased photosynthesis due to stomata closure. Reduction in photosynthesis decreased and growth regulators, which resulted in reduced turgid pressure, reduced leaf area and decreased growth.

Table 1. Effects of genotypes and different irrigation regimes on plant height, girth, number of nodes, number of leaves, and leaf area.

\begin{tabular}{|c|c|c|c|c|c|}
\hline Treatment & plant height $(\mathrm{cm})$ & girth $(\mathrm{cm})$ & node number & leaf number & leaf area $\left(\mathrm{cm}^{2}\right)$ \\
\hline variety & $* * *$ & $* * *$ & $* * *$ & $* *$ & $* * *$ \\
\hline H823 & $46.41 \mathrm{a}$ & $0.785 \mathrm{ab}$ & $12.5 \mathrm{a}$ & $25.31 \mathrm{a}$ & $20.5 \mathrm{a}$ \\
\hline H857 & $37.27 \mathrm{bc}$ & $0.73 b c$ & $11.36 \mathrm{bc}$ & $21.44 \mathrm{ab}$ & $46.8 b$ \\
\hline H674 & $30.52 d$ & $0.52 \mathrm{~d}$ & $11.94 \mathrm{ab}$ & $13.99 \mathrm{c}$ & $55.8 \mathrm{a}$ \\
\hline H739 & $44.63 a$ & $0.79 a$ & $11.47 \mathrm{bc}$ & $23.78 \mathrm{ab}$ & $23.44 \mathrm{c}$ \\
\hline H929 & $36.95 \mathrm{c}$ & $0.69 \mathrm{c}$ & $10.69 \mathrm{~d}$ & $19.76 b$ & $51.9 \mathrm{ab}$ \\
\hline H981 & $40.78 b$ & $0.78 \mathrm{ab}$ & $10.96 \mathrm{dc}$ & $19.69 \mathrm{~b}$ & $47.5 b$ \\
\hline Irrigation & $* * *$ & $* * *$ & $* * *$ & $* * *$ & $*$ \\
\hline $33 \% \mathrm{FC}$ & $30.04 b$ & $0.53 b$ & $10.24 b$ & $12.85 \mathrm{~b}$ & $38.25 b$ \\
\hline $66 \% \mathrm{FC}$ & $44.19 \mathrm{a}$ & $0.81 \mathrm{a}$ & $11.93 \mathrm{a}$ & $25.27 \mathrm{a}$ & $40.02 \mathrm{~b}$ \\
\hline $100 \% \mathrm{FC}$ & $44.05 \mathrm{a}$ & $0.82 \mathrm{a}$ & $12.30 \mathrm{a}$ & $23.87 \mathrm{a}$ & $44.75 \mathrm{a}$ \\
\hline LSD@0.05 & 2.65 & 0.05 & 0.46 & 3.41 & 4.5 \\
\hline variety*Irrigation & ns & $*$ & ns & ns & $*$ \\
\hline $\mathrm{CV}(\%)$ & 9.80 & 9.36 & 5.85 & 24.01 & 16.0 \\
\hline
\end{tabular}

*Significant at $\mathrm{p}<0.05, * *$ significant at $\mathrm{p}<0.01$ and $* * *$ significant at $\mathrm{p}<0.001$

\subsection{Plant Dry Matter Yield}

The both variety and irrigation significantly affected all characters measured in terms of leaf, stem and root dry weight as well as total dry matter yield. On another hand, the Genotype X irrigation interactions were significant $(p<0.001)$ for LDW, SDW, RDW and TDY. The dry biomass production of leaves stems and roots over period of experiment had highly increased with increasing irrigation water to some extent and dropped as irrigation water decreased. Thus, $40 \%$ ETc irrigation amount had significantly reduced the plant dry biomass (stem, leave, root, total dry biomass yield), while $80 \%$ ETc and $100 \%$ ETc irrigations levels did not differed. Regarding genotypes, H-823 had produced the heaviest stem dry, leaf dry, root dry and total dry matter yield while H-739 had produced maximum root dry matter at expense of leaf and steam dry weight.

Similarly, each genotype significantly responded to different irrigation amounts with respect of producing greater dry biomass (stem, leave and roots). Therefore, most genotypes responded highly to $80 \%$ ETc and they produce higher stem dry, leaf dry and root dry weight relatively. I contrast; under $40 \%$ ETc level plant dry biomass production was significantly inhibited. For example, this phenomena is justified by H-823 which produced heaviest leave (15.3 g), stem (13.46 g), root and total dry matter (37.35 g) under $80 \%$ ETc irrigation level, but lower dry biomass was produced under $40 \%$ ETc and medium under $120 \%$ ETc levels. This indicated that the best irrigation strategy for most genotypes and especially for H-823 was found to be $80 \%$ ETc. Similarly, [21] demonstrated that a significant reduction of dry matter in all different parts of drought- treated trees including leaves, main branches, lateral branches and roots. Similarly, the study of [19] on coffee seedling investigated that leaf dry weight; shoot dry matter yield and total dry matter production were considerably higher for the well watered than deficit irrigation. Moreover [22] reported that the root growth of loblolly and Scotch pine seedlings is significantly reduced in drying soil than normally irrigated plant. Therefore, the decrease in total dry matter yield of coffee seedlings in deficit irrigation could be attributed to the reduced total leaf area, which might have reduced the photosynthetic capacity of plants.

\subsection{Water Productivity}

The interaction effect of variety and irrigation were significantly $(\mathrm{P}<0.0001)$ differed in water use efficiencies due to variety and irrigations. The water productivity was significantly increased with decreased irrigation water. Accordingly $40 \%$ ETc of irrigations produced maximum water productivity and followed by $80 \% \mathrm{ETc}$, while the least had from $120 \% \mathrm{ETc}$ with the corresponding values of $4.2,3.7$ and $2.45 \mathrm{~g} /$ liter, respectively. Irrespective of genotypes, almost all genotypes differentially responded to irrigation amounts, consequently, the highest and lowest water productivity had produced from $\mathrm{H}-823$ and $\mathrm{H}-929$, respectively, but similar values was observed among $\mathrm{H}-857$ and $\mathrm{H}-981$ genotypes under varies irrigation levels. Moreover, H-823 had produced highest water productivity under $80 \%$ ETc and followed by $\mathrm{H}-$ $674, \mathrm{H}-857$ and H-929 under $40 \%$ ETc. In contrast, the lowest water productivity had from $\mathrm{H}-981$ and $\mathrm{H}-674$ under $120 \%$ ETc irrigation level. Despite $50 \%$ and $66.7 \%$ reduction in volume of water applied, $40 \% \mathrm{ETc}$ increased water productivity by more than $47.6 \%$ and $11.9 \%$ over $120 \%$ ETc 
and $80 \% \mathrm{ETc}$ treatments. This indicated that as the volume of water decreased the water productivity significantly increased. However, some coffee genotypes produced maximum water productivity under $80 \% \mathrm{ETc}$ this was especially true for $\mathrm{H}-823$. In general, most genotypes gave maximum water productivity under $40 \% \mathrm{ETc}$ irrigation levels. In contrast, under $40 \% \mathrm{ETc}$, coffee seedling exhibited lower dry matter production and retarded plant growth. But under $80 \% \mathrm{ETc}$ irrigation level, coffee seedlings gave medium water use efficiency, maximum dry matter and promoted vegetative growth. Therefore, the best irrigation strategy for coffee seedlings was found to be $80 \%$ of ETc under nursery conditions. This result closely agree with [19] finding that water productivity of coffee seedlings substantially improved with the deficit irrigation.

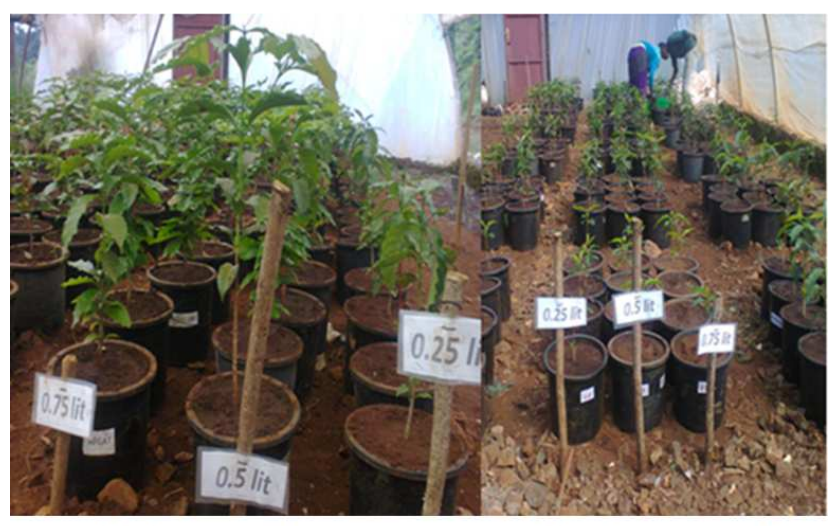

After Application of Treatment

Before Treatment Started

Figure 2. Response coffee genotypes to deficit.

Table 2. Effect of genotypes and deficit irrigation on SDW, LDW, TDMand WUE.

\begin{tabular}{|c|c|c|c|c|c|c|c|c|}
\hline Treatment & $\begin{array}{l}\text { SFW } \\
\text { (gm/plant) }\end{array}$ & $\begin{array}{l}\text { SDW } \\
\text { (gm/plant) }\end{array}$ & $\begin{array}{l}\text { LFW } \\
\text { (gm/pant) }\end{array}$ & $\begin{array}{l}\text { LDW } \\
\text { (gm/plant) }\end{array}$ & $\begin{array}{l}\text { RFW } \\
\text { (gm/plant) }\end{array}$ & $\begin{array}{l}\text { RDW } \\
\text { (gm/plant) }\end{array}$ & $\begin{array}{l}\text { TDY } \\
\text { (gm/plant) }\end{array}$ & $\begin{array}{l}\text { WP } \\
\text { (gm/liter) }\end{array}$ \\
\hline Variety & $* * *$ & $* * *$ & $* * *$ & $* * *$ & $* * *$ & $* *$ & $* * *$ & $* * *$ \\
\hline H823 & $15.84^{\mathrm{b}}$ & $10.27^{\mathrm{a}}$ & $23.57^{\mathrm{a}}$ & $11.03^{\mathrm{a}}$ & $19.77^{\mathrm{b}}$ & $7.35^{\mathrm{a}}$ & $28.65^{\mathrm{a}}$ & $3.86^{\mathrm{a}}$ \\
\hline H857 & $12.16^{\mathrm{b}}$ & $7.93^{\mathrm{d}}$ & $20.98^{\mathrm{bc}}$ & $9.92^{\mathrm{bc}}$ & $17.26^{\mathrm{c}}$ & $7.03^{\mathrm{ab}}$ & $24.87^{\mathrm{c}}$ & $3.42^{\mathrm{bc}}$ \\
\hline H674 & $10.52^{\mathrm{e}}$ & $6.78^{\mathrm{e}}$ & $17.85^{\mathrm{d}}$ & $9.03^{\mathrm{d}}$ & $12.08^{\mathrm{e}}$ & $6.47^{\mathrm{bc}}$ & $22.28^{\mathrm{d}}$ & $3.13^{\mathrm{d}}$ \\
\hline H739 & $17.07^{\mathrm{a}}$ & $8.83^{\mathrm{b}}$ & $22.13^{\mathrm{b}}$ & $10.30^{\mathrm{b}}$ & $21.31^{\mathrm{a}}$ & $7.48^{\mathrm{a}}$ & $26.62^{\mathrm{b}}$ & $3.52^{\mathrm{b}}$ \\
\hline H929 & $14.14^{\mathrm{c}}$ & $8.43^{c}$ & $20.38^{\mathrm{c}}$ & $9.75^{\mathrm{c}}$ & $15.31^{\mathrm{d}}$ & $6.11^{\mathrm{c}}$ & $24.28^{\mathrm{c}}$ & $3.36^{\mathrm{c}}$ \\
\hline CV $(\%)$ & 4.7 & 3.95 & 6.46 & 5.5 & 5.80 & 9.68 & 3.23 & 4.65 \\
\hline LSD@0.05 & 0.65 & 0.32 & 1.35 & 0.54 & 0.99 & 0.65 & 0.79 & 0.15 \\
\hline Irrigation & $* * *$ & $* * *$ & $* * *$ & $* * *$ & $* * *$ & $* * *$ & $* * *$ & $* * *$ \\
\hline $33 \% \mathrm{FC}$ & $6.65^{\mathrm{c}}$ & $6.01^{\mathrm{b}}$ & $5.17^{\mathrm{c}}$ & $5.39^{\mathrm{b}}$ & $7.28^{\mathrm{c}}$ & $5.43^{b}$ & $16.82^{\mathrm{b}}$ & $4.20^{\mathrm{a}}$ \\
\hline $66 \% \mathrm{FC}$ & $19.18^{\mathrm{a}}$ & $9.585^{\mathrm{a}}$ & $30.56^{\mathrm{a}}$ & $12.40^{\mathrm{a}}$ & $24.51^{\mathrm{a}}$ & $7.61^{\mathrm{a}}$ & $29.60^{\mathrm{a}}$ & $3.70^{\mathrm{b}}$ \\
\hline $100 \% \mathrm{FC}$ & $16.94^{\mathrm{b}}$ & $9.73^{\mathrm{a}}$ & $29.19^{\mathrm{b}}$ & $12.14^{\mathrm{a}}$ & $20.86^{\mathrm{b}}$ & $7.60^{\mathrm{a}}$ & $29.46^{\mathrm{a}}$ & $2.45^{\mathrm{c}}$ \\
\hline LSD@0.05 & 0.46 & 0.23 & 0.96 & 0.38 & 0.70 & 0.45 & 0.56 & 0.11 \\
\hline
\end{tabular}

*, **, ***, which is significant at $\mathrm{p}<0.05$, at $\mathrm{p}<0.01$ and at $\mathrm{p}<0.001$, respectively, SDW=stem dry weight, LDW= leaf dry weight, RDW $=$ root dry weight, $\mathrm{TDY}=$ total dry matter yield, $\mathrm{WP}=$ water productivity.

Table 3. Interaction effects of deficit irrigation and coffee genotypes on dry biomass yield and water productivity.

\begin{tabular}{|c|c|c|c|c|c|c|c|}
\hline Variety level & Irrigation level & $\begin{array}{l}\text { SDW } \\
\text { (gm/plant) }\end{array}$ & $\begin{array}{l}\text { LDW } \\
\text { (gm/plant) }\end{array}$ & $\begin{array}{l}\text { RDW } \\
\text { (gm/plant) }\end{array}$ & $\begin{array}{l}\text { TDM } \\
\text { (gm/plant) }\end{array}$ & WP (g/liter) & Leaf area $\left(\mathrm{cm}^{2}\right)$ \\
\hline H823 & $40 \%$ ETc & $6.25 \mathrm{fg}$ & $5.83 \mathrm{gh}$ & $5.187 \mathrm{f}$ & $17.26 \mathrm{fg}$ & $4.31 \mathrm{~b}$ & $19.74 f$ \\
\hline H823 & $80 \%$ ETc & $13.46 \mathrm{a}$ & $15.30 \mathrm{a}$ & $8.59 \mathrm{a}$ & $37.36 \mathrm{a}$ & $4.67 \mathrm{a}$ & $53.18 \mathrm{ab}$ \\
\hline H823 & $120 \%$ ETc & $11.10 \mathrm{~b}$ & $11.95 \mathrm{c}-\mathrm{e}$ & $8.28 \mathrm{ab}$ & $31.33 b$ & $2.61 \mathrm{f}-\mathrm{h}$ & $52.63 \mathrm{ab}$ \\
\hline H857 & $40 \% \mathrm{ETc}$ & $6.60 \mathrm{f}$ & $5.47 \mathrm{~h}$ & $5.19 \mathrm{f}$ & $17.25 \mathrm{fg}$ & $4.31 \mathrm{~b}$ & $20.89 f$ \\
\hline H857 & $80 \%$ ETc & $8.48 \mathrm{~d}$ & $11.43 \mathrm{e}$ & $8.60 \mathrm{a}$ & $28.51 \mathrm{c}$ & $3.57 \mathrm{~d}$ & $42.82 \mathrm{bcd}$ \\
\hline H857 & $120 \%$ ETc & $8.70 \mathrm{~d}$ & $12.86 \mathrm{bc}$ & $7.3 \mathrm{bcd}$ & $28.86 \mathrm{c}$ & $2.41 \mathrm{ih}$ & $40.27 \mathrm{~cd}$ \\
\hline H674 & $40 \% \mathrm{ETc}$ & $5.34 \mathrm{~h}$ & $6.59 \mathrm{~g}$ & $5.66 \mathrm{ef}$ & $17.59 \mathrm{f}$ & $4.40 \mathrm{ab}$ & $18.32 \mathrm{f}$ \\
\hline H674 & $80 \%$ ETc & $6.62 f$ & $8.69 f$ & $6.21 \mathrm{~d}-\mathrm{f}$ & $21.52 \mathrm{e}$ & $2.69 f$ & $35.29 \mathrm{de}$ \\
\hline H674 & $120 \%$ ETc & $8.39 \mathrm{~d}$ & $11.8 \mathrm{de}$ & $7.54 \mathrm{a}-\mathrm{c}$ & $27.73 \mathrm{~cd}$ & $2.31 \mathrm{i}$ & $58.91 \mathrm{a}$ \\
\hline H739 & $40 \%$ ETc & $5.75 \mathrm{gh}$ & $4.04 \mathrm{hi}$ & $5.67 \mathrm{ef}$ & $15.46 \mathrm{~g}$ & $3.87 \mathrm{c}$ & $24.72 \mathrm{ef}$ \\
\hline H739 & $80 \% \mathrm{ETc}$ & $10.48 \mathrm{c}$ & $13.37 \mathrm{~b}$ & $8.39 \mathrm{ab}$ & $32.23 b$ & $4.03 c$ & $53.22 \mathrm{ab}$ \\
\hline H739 & $120 \%$ ETc & $10.27 \mathrm{c}$ & $13.51 \mathrm{~b}$ & $8.41 \mathrm{ab}$ & $32.19 b$ & $2.68 \mathrm{fg}$ & $49.65 \mathrm{abc}$ \\
\hline H929 & $40 \%$ ETc & $6.59 f$ & $5.470 \mathrm{~h}$ & $5.51 \mathrm{ef}$ & $17.57 f$ & $4.39 b$ & $23.49 \mathrm{ef}$ \\
\hline H929 & $80 \%$ ETc & $7.33 \mathrm{e}$ & $12.69 b-d$ & $6.26 \mathrm{def}$ & $26.28 \mathrm{de}$ & $3.29 \mathrm{e}$ & $52.08 \mathrm{abc}$ \\
\hline H929 & $120 \%$ ETc & $11.37 \mathrm{~b}$ & $11.09 \mathrm{e}$ & $6.55 \mathrm{cde}$ & $29.01 \mathrm{c}$ & $2.42 \mathrm{~g}-\mathrm{i}$ & $55.89 \mathrm{a}$ \\
\hline H981 & $40 \%$ ETc & $5.50 \mathrm{~h}$ & 4.95hi & $5.363 \mathrm{ef}$ & $15.81 \mathrm{fg}$ & $3.95 \mathrm{c}$ & $24.71 \mathrm{ef}$ \\
\hline H981 & $80 \%$ ETc & $11.15 b$ & $12.95 \mathrm{bc}$ & $7.64 a-c$ & $31.74 b$ & $3.97 \mathrm{c}$ & $59.65 a$ \\
\hline H981 & $120 \%$ ETc & $8.54 \mathrm{~d}$ & $11.59 \mathrm{e}$ & $7.54 \mathrm{a}-\mathrm{c}$ & $27.66 \mathrm{~cd}$ & $2.31 \mathrm{i}$ & $52.68 \mathrm{ab}$ \\
\hline LSD@0.05 & & 0.56 & 1.01 & 1.28 & 1.9 & 0.33 & 11.7 \\
\hline
\end{tabular}

Means followed by the same letters in column are not statistically different at $5 \%$ level for Least Significant Difference Test. $*$ Significant at $\mathrm{p}<0.05$, $* *$ significant at $\mathrm{p}<0.01$ and $* * *$ significant at $\mathrm{p}<0.001$ 


\subsection{Correlations Between Water Use Efficiency and Growth Traits}

Highly significant correlation of water productivity with most plant traits were noted in $80 \% \mathrm{ETc}$ than other water amounts, due to optimum moisture supply. The plants treated with optimum moisture enhanced photosynthetic assimilation thereby finally improve both dry biomass accumulation and water productivity. However, this relationship becomes diminished under stress greatly as well as under surplus moisture supply condition at lesser extent. Furthermore, the water productivity did not correlate with all plant traits in $40 \% \mathrm{ETc}$ due to retardation of plant growth as affected by moisture stress. Therefore, as supply of irrigation water increased to some extent plant height, girth and number of leaves were significantly increased, but as moisture supply approaches to $120 \% \mathrm{ETc}$, the plant growths become affected. Furthermore, the positive correlation of water productivity with plant growth may due to the fact that the ticker plant and tallest plant produce higher dry mater which improves the water productivity.

Table 4. Relationship of water productivity with plant traits.

\begin{tabular}{llll}
\hline \multirow{2}{*}{ Traits } & \multicolumn{2}{l}{ WP } & \\
\cline { 2 - 4 } & $\mathbf{4 0 \% E T c}$ & $\mathbf{8 0 \% E T c}$ & $\mathbf{1 2 0 \% E T c}$ \\
\hline Plant Height & $0.10 \mathrm{~ns}$ & $0.87^{* *}$ & $0.59^{*}$ \\
Stem Girth & $0.12^{\text {ns }}$ & $0.73^{* *}$ & $0.47^{*}$ \\
Number of Nodes & $0.10^{\text {ns }}$ & $0.14^{\text {ns }}$ & $0.18^{\text {ns }}$ \\
Number of Leaves & $0.26^{\text {ns }}$ & $0.70^{* *}$ & $0.38^{\text {ns }}$ \\
Leaf Area & $-0.26^{\text {ns }}$ & $0.59^{*}$ & $0.09^{\text {ns }}$ \\
\hline
\end{tabular}

$*, * *, * * *$ Significant at $\mathrm{p}<0.05, \mathrm{p}<0.01$ and $\mathrm{p}<0.0001$ levels, respectively. $\mathrm{ns}$, Non-significant, WP- water use productivity.

\section{Conclusion}

From this experiment we concluded that the water use efficiency was significantly increased with decreased irrigation water. Irrigating coffee seedlings with $40 \%$ of ETc produced maximum water use efficiency and followed by $80 \%$ ETc but least had from $120 \%$ of ETc. Almost all genotypes differentially responded to irrigation amounts, the highest and lowest water use efficiency had produced from $\mathrm{H}-823$ and H-929, respectively, but similar values was observed among $\mathrm{H}-857$ and $\mathrm{H}-981$ genotypes with all irrigations. In contrast, irrigating coffee seedlings with $40 \%$ of ETc can greatly inhibit plant growth and development. But irrigating coffee seedling with $80 \%$ of ETc optimized water use efficiency as well as enhances vegetative growth. Therefore, irrigating coffee seedling with $80 \%$ of ETc can produce higher dry matter production and greater water productivity, it can save considerable amount of water when compared to $120 \%$ of ETc irrigation level. This finding, however, needs to be verified in replicated field trials under various agro-ecological circumstances.

\section{Conflict of Interest}

The authors declare that they have no competing interests.

\section{Acknowledgements}

The author wishes to express his gratitude to the JARC in general for giving invaluable assistance in the completion of the study, and in particular to the EIAR for financial support.

\section{References}

[1] ICO. 2021. International Coffee Organization. Annual Review. http://www.ico.org/

[2] Tesfaye, S. G, Ismail, M. R., and Mahmood, M., 2008. Effects of deficit irrigation and partial rootzone drying on growth, dry matter partitioning and water use efficiency in young coffee (Coffea arabica L.) plants. Journal of Food, Agriculture \& Environment Vol. 6 (3 \& 4): 312-317. 2008.

[3] DaMatta, F. M. and Ramalho, J. D. C., 2006. Impacts of drought and temperature stress on coffee physiology and production: a review. Brazilian journal of plant physiology, 18 (1), pp. 55-81.

[4] DaMatta, F. M., 2004. Exploring drought tolerance in coffee: a physiological approach with some insights for plant breeding. Brazilian journal of plant physiology, 16 (1), pp. 1-6.

[5] Seckler D, Young, RA. 1985. The choices of irrigation technologies in California. American Journal of Agricultural Economics 67: 2.

[6] USDA. 1997. Agricultural resources and environmental indicators, 1996-97. Agricultural Handbook No. 712. Economic Research Service, United States Department of Agriculture. (Available from http://www.ers.usda.gov/publications/ahagriculturalhandbook/ah712.aspx\#.Ucwf_fnI2So) (Accessed on 27 June 2013).

[7] Sharma, B., David, M. and Simon C. n.d. Water use efficiency in agriculture: Measurement, current situation and trends. International Water Management Institute (IWMI), New Delhi, India, b.sharma@cgiar.org pp 51-52.

[8] Jensen, M. E. 2007. Beyond irrigation efficiency, Irrig. Sci., 25, 233-245, doi: 10.1007/s00271-007-0060-5.

[9] Viets, F. G. 1962. Fertiliser and efficient use of water. Advances in Agronomy 14: 223- 264.

[10] Steduto, P., Hsaio, T. C., Fereres, E. 2007. On the conservative behavior ofbiomass water productivity. Irrigation Science 25: 189-207.

[11] Li, Y. S. 1982. Evaluation of field soil moisture condition and the ways to improve crop water use efficiency in Weibei region. Journal of Agronomy in Shaanxi Province, 2, 1-8.

[12] Farahani, H. A., Valadabadi, S. A., Daneshian, J., Shiranirad, A. H. and Khalvati, M. A. 2013. Review on Medicinal and aromatic plants farming under drought conditions. African Journal of Plant Breeding Vol. 1 (5), pp. 083-088.

[13] Ludlow, M. M. and R. C. Muchow. 1990. A critical evaluation of traits for improving crop yields in water-limited environments. Adv. Agron. 43: 107-153. 
[14] Yoo, C. Y., H. E. Pence, P. M. Hasegawa, and M. V. Mickelbart. 2009. Regulation of transpiration to improve crop water use. Crit. Rev. Plant Sci. 28: 410.

[15] Bassil, E. S. and Kaffka, S. R. 2002. Response of safflower (Carthamustinctorius L.) to saline soils and irrigation: I. Consumptive water use. Agr. Water Mgt. 54: 67-80.

[16] Morison, J. I.., Baker, N.., Mullineaux, P.., \& Davies, W.. (2008). Improving water use in crop production. Philosophical Transactions of the Royal Society B: Biological Sciences, 363 (1491), 639-658. doi: 10.1098/rstb.2007.2175.

[17] You-, B. Y, Dan-yan. C, Xiao, H., Yu-Hua L, Fuzhang, D. and Chantal K. 2012. Effects of different irrigation quantities on plant growth and photosynthesis characters of flue-cured tobacco. Journal of Food, Agriculture \& Environment Vol. 10 (2): pp 1160-1163.
[18] Taye, K. 2012. Biomass production and distribution in seedlings of Coffea arabica genotypes under contrasting nursery environments in southwestern Ethiopia. Agricultural Sciences, 3 (06), p. 835.

[19] Tesfaye, S. G., 2008. Effects of deficit irrigation and partial rootzone drying on growth, dry matter partitioning and water use efficiency in young coffee (Coffea arabica L.) plants.

[20] Kramer, P. J. 1969. Plant and water relationship. Mc GrawHill book company, New York, pp: 347-390.

[21] Rad, A. H. S. and Abbasian, A., 2011. Evaluation of drought tolerance in winter rapeseed cultivars based on tolerance and sensitivity indices. Žemdirbystė (Agriculture), 98 (1), pp. 41-48.

[22] Kaufmann MR (1968) Evaluation of the pressure chamber method. Proc Am Soc Hortic Sci 93: 186. 